\title{
S onu stranu standardnog tiska
}

\author{
Jelena Lešaja \\ Hrvatska knjižnica za slijepe, Zagreb, Hrvatska \\ jelena.lesaja@hkzasl.hr
}

\section{Sažetak}

Tekst govori o dostupnosti pisane riječi i putovanju kojeg ona prolazi kako bi dospjela do korisnika kojima standardni tisak nije čitljiv. Navode se načini, oblici i mediji koji pomažu u izradi i korištenju dostupnog naslova. Tehnološke promjene (od analogne do digitalne ere; od kazeta do CD-a i usluge preuzimanja) u sinergiji s promjenama u strukturi korisnika (od slijepih osoba do osoba s teškoćama u čitanju i učenika s disleksijom) transformiraju proizvodnju knjižničnog fonda. Na primjeru Hrvatske knjižnice za slijepe objašnjava se produkcija knjiga na brajici i u zvuku te se spominju usluge karakteristične za knjižnice namijenjene osobama kojima standardni tisak nije čitljiv. Specifičnosti korisničkog profila i čitateljskih navika govore o tome kako želja za čitanjem daleko nadmašuje produkciju i ponudu literature.

Ključne riječi: osobe kojima standardni tisak nije čitljiv, brajica, zvučna knjiga, asistivna tehnologija, slijepe osobe, Hrvatska knjižnica za slijepe, dostupni oblici

\section{Uvod}

Kako, što i koliko čitaju osobe koje ne mogu čitati standardni tisak? Prije nego što se pokuša odgovoriti na ova pitanja treba se pozabaviti s osnovnom preprekom koja dijeli čitatelje standardnog tiska i one koji to nisu. Pokretač u poslovanju knjižnica namijenjenih osobama kojima standardni tisak nije čitljiv je dostupnost, odnosno nedostupnost štiva, znanja i informacija. Izuzmu li se režimska cenzura, ekonomski uvjeti i jezične barijere, osobama koje čitaju standardni tisak sve napisano je u suštini, u kvantitativnom i formalnom smislu, neprekidno na raspolaganju. Onima koji ne mogu čitati standardni tisak dostupno je tek 5\%. ${ }^{1}$ Količinu i raspon svega što je u svijetu obilježeno standardnim pismom teško je pojmiti. Osim literature koja se svakodnevno tiska na standardnom tisku, osobama koje ga ne mogu čitati nisu dostupne ni najobičnije sitnice poput natpisa ulica, upozorenja u prometu, menija u restoranima, naziva na ambalažama proizvoda, uputa za rukovanje kućanskim aparatima i sl. Medij standardnog, popularno nazvanog - crnog tiska, za osobe koje ga ne mogu čitati je poput zatvorene crne kutije čiji sadržaj u isto vrijeme postoji i ne postoji.

\section{Dostupnost pisanog teksta}

Za slijepe osobe je izum Louisa Braillea, unatoč pokušajima koji su se redali prije toga, bio istinsko otvaranje svijeta pisanog govora. Ono je pismenost slijepih ljudi učinilo aktivnom. ${ }^{2}$ Tehnološka otkrića koja su uslijedila u posljednjih dvjestotinjak godina i brzina kojom su se nadopunjavala, pogodovala su razvoju asistivne tehnologije i samostalnosti njenih korisnika. Brajica ${ }^{3}$

\footnotetext{
${ }^{1}$ Prema podacima Svjetskog saveza slijepih, od preko jednog milijuna naslova obajvljenih svake godine u svijetu tek je $5 \%$ napravljenih u dostupnim formatima. WIPO, "Limitations and Exceptions: Access to Books for the Visually Impaired", http://www.wipo.int/pressroom/en/briefs/limitations.html (preuzeto 31. 8. 2017).

2 Više o pismu za slijepe: Centar za odgoj i obrazovanje "Vinko Bek”, „Specifični programi rehabilitacije”, http://www.centar-vinko-bekzg.skole.hr/nastava/specificni-programi-rehabilitacije?ms_nav=aad (preuzeto 31. 8. 2017).

${ }_{3}^{3}$ Brajica - udomaćen hrvatski naziv za Braillovo pismo, osmislio je Mirko Vidulić, korisnik i bivši djelatnik Knjižnice (napomena autorice teksta).
} 
se više nije trebala pisati ručno, postojale su pisaće mašine, tiskarske preše i strojevi. Osmišljeni su softveri za konverziju teksta sa standardnog tisku u brajicu i ispisivači raznih dimenzija i kapaciteta.

U međuvremenu, većina zemalja u svijetu otvarala je obrazovne ustanove, saveze i udruge namijenjene slijepim i slabovidnim osobama. ${ }^{4}$ Pri tim su udrugama osnivane isprva zbirke i čitaonice, a zatim i knjižnice koje su unatrag tridesetak godina počele težiti osamostaljenju. Ono što je knjižnice za slijepe i slabovidne uglavnom činilo specifičnim ${ }^{5}$ je to da su one same proizvodile svoj fond. Tržište, a samim time i nabava, komercijalno proizvedenih knjiga u adekvatnim formatima, posebice u zemljama uskog govornog područja, do kraja 20. stoljeća bila je gotovo zanemariva. Osim knjiga koje su se tiskale na brajici, od sredine 20. stoljeća u knjižnicama za slijepe se počinju snimati zvučne knjige. Razvoj medija zvučne knjige također se kretao usporedo s tehnološkim razvojem reproduktora i nosača zvuka, od magnetofonskih vrpci, ploča, kaseta, kompaktnih diskova do digitalnih zvučnih zapisa u mp3, Daisy i e-pub formatima. Proizvodnja zvučnih knjiga, koje su činile sve veći dio fonda, otvorila je vrata knjižnica za slijepe i slabovidne novim korisničkim populacijama. Potreba za čitanjem na alternativnim medijima, nastala iz nužde, bila je zapravo veća nego što se moglo pretpostaviti. Osobe s degenerativnim promjenama oka, osobe treće životne dobi, učenici s teškoćama u čitanju i disleksijom, osobe s motoričkim oštećenjima koja im trajno ili privremeno onemogućavaju praćenje standardnog tiska, tijekom nekoliko su desetljeća temeljito promijenila korisnički profil knjižnica za slijepe.

Proces kojeg knjiga na standardnom tisku prolazi kako bi postala dostupna, u slučaju brajice, ali i zvučnog i xml formata, zahtjevan je u proizvodnom i u financijskom smislu. Chris Friend, jedan od najvećih boraca za prava osoba kojima standardni tisak nije čitljiv, jednom je prilikom napomenuo kako se knjiga ne smije smatrati doista objavljenom prije nego što postane dostupna. Iz tih se razloga u lipnju 2013. godine sastavio Ugovor iz Marakeša. ${ }^{6}$

\section{Načini čitanja dostupnih formata}

Načini čitanja mijenjali su se s razvojnom putanjom tehnologija. ${ }^{7}$ Način čitanja, korištenje medija i njemu pripadajućih reprodukcijskih tehnologija također ovisi o kategoriji korisnika. Jezgra korisničke populacije svake knjižnice namijenjene onima koji ne mogu čitati standardni tisak su slijepe osobe. Časopisi i knjige otisnuti brajicom temelj su (nažalost, sve više simboličan) fondova dotičnih knjižnica, te se njime služe isključivo slijepi i gluho-slijepi korisnici. Unatoč napredovaloj tehnologiji koja omogućava čitanje digitalnog sadržaja pomoću brajevog retka i brajeve elektroničke bilježnice, broj osoba koje se koriste brajicom je u velikom padu. Trend je prisutan u

\footnotetext{
${ }^{4}$ O povijesti Hrvatske knjižnice za slijepe vidjeti Sanja Frajtag, „50 nam je godina već”, HKD Novosti 68 (2016), http://www.hkdrustvo. $\mathrm{hr} / \mathrm{hkdnovosti/broj/65}$ (preuzeto 31. 8. 2017).

${ }^{5}$ Specifičnost knjižnica namijenjenih osobama kojima standardni tisak nije čitljiv ne bi se trebala miješati sa specijalnim knjižnicama kao tipom. Specijalna knjižnica građom je vezana uz specifično polje, a korisnici su vezani uz instituciju koju knjižnica opslužuje. Fond, korisnici i njihove čitateljske navike u knjižnicama poput Hrvatske knjižnice za slijepe identični su narodnim knjižnicama samo što je građa prenesena u dostupan format (napomena autorice teksta).

${ }^{6}$ Ugovor iz Marakeša je stupio na snagu 30. rujna 2016. godine, nakon što ga je ratificirala Kanada, čime je postignut broj od 20 država potpisnica. 10. svibnja je donesen sporazum između Europskog parlamenta, Europske komisije i Vijeća ministara o tekstu Direktive i Uredbe za provedbu Ugovora iz Marakeša. Ugovorom bi se, kroz ustupke u zakonima o autorskom pravu pri izradi materijala u dostupnim formatima, osobama koje ne čitaju standardni tisak omogućio slobodan pristup znanju i informaciji koji im je za sada blokiran. Njime bi se zaustavila tzv. book famine iliti glad za knjigom jer se procjenjuje kako je u svijetu svega 5\% od ukupne produkcije knjiga, časopisa, znanja i informacije dostupno osobama koje ne čitaju standardni tisak. Izdavači bi svako svoje izdanje na standardnom tisku ovakvom direktivom bili dužni automatski izraditi i u digitalno idealnom obliku i dati na korištenje osobama koje ne čitaju standardni tisak, takva se publikacija zove born digital publication. Uredba i direktiva proizašle iz sporazuma dopuštaju prekograničnu razmjenu knjiga i drugih pisanih materijala u dostupnim formatima za slijepe i slabovidne osobe kako unutar tako i izvan Europske unije (s time da je krajnji korisnik uvijek u državi koja je ratificirala sporazum). Vidi: WIPO, "Marrakesh Treaty to Facilitate Access to Published Works for Persons Who Are Blind, Visually Impaired or Otherwise Print Disabled", http://www.wipo.int/treaties/en/ip/marrakesh/ (preuzeto 31. 8. 2017).

${ }^{7}$ U članku ne spominjem uvećani tisak i građu laganu za čitanje jer se Hrvatska knjižnica ne bavi njihovom proizvodnjom (napomena autorice teksta).
} 
svim zemljama te se slijepe osobe sve više oslanjaju, pogotovo u trenutku kada završe obavezno obrazovanje, na zvučnu tehnologiju. Time se gubi temelj pismenosti slijepih osoba i narušava užitak kojeg pruža samostalno čitanje. ${ }^{8}$

Taktilne slikovnice koje u svojoj idealnoj formi nude paralelno tekst na uvećanom tisku i na brajici s jedne strane, a taktilnu ilustraciju s druge strane, namijenjene su slijepoj i slabovidnoj djeci. Budući da je produkcija takvih slikovnica vrlo mala, one su najčešće kreativni unikati pedagoga i nastavnika, ali i brojnih entuzijasta, studenata i učenika. ${ }^{9} \mathrm{U}$ svijetu postoje zanimljive inicijative izrada taktilnih slikovnica, pa tako primjerice knjižnice surađuju preko projekata sa ženskim zatvorima gdje su štićenice angažirane i prethodno educirane kako bi izvedba bila u skladu sa standardima.

Zvučna knjiga je najpopularniji oblik dostupne knjige (prema engleskom accessible book) te je kao takva namijenjena najširem spektru korisnika izuzev gluho-slijepih osoba. Načini na koje korisnici čitaju, odnosno slušaju zvučnu knjigu, ovise o stupnju informatičke pismenosti, tehničkoj podršci, korisničkoj komociji i načinu života. Slušanje zvučnih knjiga doimlje se kao praktična varijanta čitanja koja omogućava fleksibilnost i obavljanje više paralelnih radnji te ne zahtijeva posebno izdvojeno vrijeme. Upravo zbog toga ona je sve popularnija među videćom populacijom u zemljama gdje je komercijalna proizvodnja raširena i donekle prati onu na standardnom tisku.

Knjige u strojno čitljivom formatu pristupačne su svim korisničkim skupinama koje se koriste računalom odnosno nekom formom digitalne tehnologije. Trostruka podrška zapisa - na ekranu, brajevom retku i pomoću govorne jedinice - potiče aktivno, samostalno čitanje i pasivno, zvučno. Zbog toga se ovaj format smatra dobrim za učenike s teškoćama u čitanju i disleksijom. ${ }^{10}$

\section{Korištenje i proizvodnja dostupnih naslova u Hrvatskoj knjižnici za slijepe}

Hrvatska knjižnica za slijepe u svom sastavu ima tiskaru gdje se obavljaju i sve produkcijske predradnje koje pripremaju standardni tisak za ispis na brajicu. Nastoji se popularizirati i podržati njeno čitanje, a korisnici koji se koriste isključivo tim dijelom fonda oslobođeni su plaćanja članarine. U svrhu afirmacije pismenosti slijepih osoba redovito se organiziraju državna natjecanja u brzom i izražajnom čitanju. Knjige pripremljene u strojnom formatu tiskaju se na zahtjev čitatelja i šalju nepovratno u broširanim sveščićima dok se ljeti i uoči zimskih praznika tiskaju popularne zabavne knjige i šalju na dar korisnicima.

U Hrvatskoj je komercijalna produkcija zvučnih knjiga vrlo mala već zbog ograničenog govornog područja i slabog tržišta. Hrvatska knjižnica za slijepe u svojim studijima proizvodi nekomercijalne zvučne knjige u skladu sa Zakonom o autorskom pravu, ${ }^{11}$ isključivo za potrebe svoje korisničke populacije. Korisnici Hrvatske knjižnice za slijepe koji su također članovi udruga slijepih mogu ostvariti pravo putem Hrvatskog zavoda za zdravstveno osiguranje za dodjelu reproduktora. Riječ je o specifičnim reproduktorima, stolnim i prijenosnim, koji podržavaju Daisy format. ${ }^{12}$

\footnotetext{
${ }^{8}$ Vidi esej Karen Keninger, "Why Braille?" (rad predstavljen na Tailoring the Reading Experience to Meet Individual Needs, Libraries Serving Persons with Print Disabilities 2016 Satellite Conference, Louisville, Kentucky, SAD, 11-12. kolovoza, 2016), Libraries serving persons with print disabilities, "LPD Satellite Conference: Tailoring the Reading Experience to meet Individual Needs", IFLA, https:// www.ifla.org/node/10839 (preuzeto 31. 8. 2017).

${ }^{9}$ Detaljnije u Tanja Šupe, „Smjernice za izradu taktilne slikovnice”, u Hrvatska mreža školskih knjižničara, http://www.knjiznicari.hr/ UDK02/index.php/Smjernice_za_izradu_taktilne_slikovnice_-_Tanja_\%C5\%A0upe) (preuzeto 31. 8. 2017).

${ }^{10}$ Više o alatima i načinima čitanja podobnim za učenike s teškoćama u čitanju i disleksijom Luc Maumet, "Accessibility in reading systems: what about dyslexia?", EdrLAB, https://www.edrlab.org/2017/06/20/accessibility-in-reading-systems-what-about-dyslexia/ (preuzeto 31. 8. 2017).

11 U 86. čl. hrvatskog Zakona o autorskom pravu stoji: „Za potrebe osoba s invalidnošću dopušteno je korištenje autorskih djela na način koji je izravnoj vezi s invalidnošću tih osoba i koje je nekomercijalne naravi, a u opsegu potrebnom za odnosnu invalidnost". Hrvatski sabor, „Zakon o autorskom pravu”, Narodne novine 167 (2003), http://narodne-novine.nn.hr/clanci/sluzbeni/2003_10_167_2399.html (preuzeto 31. 8. 2017).

${ }^{12}$ DAISY digitalni format knjige osmišljen je kao kompletna zvučna zamjena za tiskani materijal i posebno je namijenjena za osobe kojima standardni tisak nije čitljiv. Temeljeći se na MP3 i XML formatima, DAISY format ima napredne navigacijske mogućnosti, uz one već prisutne u tradicionalnim audio knjigama. Daisy consortium, http://www.daisy.org/home (preuzeto 31. 8. 2017).
} 
Korisnici koji ne ostvaruju pravo podrške asistivne tehnologije mogu bez smetnji slušati knjige iz fonda Knjižnice na običnim reproduktorima, računalima i mobitelima koji podržavaju (ili konvertiraju) mp3 format. Zbog izuzetno brzog mijenjanja u trendovima proizvodnje i reprodukcije digitalnih formata dosta je teško proizvesti čvrste smjernice i strateške planove. Jednako tako ih se teško pridržavati jer, primjerice, unesu li se inovacije u proizvodnji i plasiranju usluga, postoji opasnost da ih se neće moći propratiti u smislu korisniče podrške (korisnici preko zdravstvenog osiguranja ostvaruju pravo na novi reproduktor svakih pet godina).

Hrvatska knjižnica za slijepe proizvodi i knjige u strojno čitljivom, xml formatu. Produkcija ovog formatu isprva je bila zamišljena isključivo za potrebe učenika, te su veći dio sačinjavali lektirni naslovi. S vremenom se produkcija proširila na naslove koji se paralelno proizvode s onima na brajici. Unatoč njegovoj praktičnosti i sveobuhvatnosti, xml format ostaje i dalje najmanje popularan format među korisnicima.

\section{Navike korisnika Hrvatske knjižnice za slijepe}

Kao što je ranije spomenuto, zbog brojnih društvenih faktora, knjižnice prvotno namijenjene slijepima, pa onda i slabovidnim osobama, svuda su u svijetu otvorile svoja vrata širokoj kategoriji onih kojima standardni tisak nije čitljiv. Bolja liječnička skrb i napredak u dijagnostici utjecali su na smanjen broj slijepe djece, dok su produžen životni vijek, senzibilizacija okoline i tehnološka dostignuća uzrokovali porast drugih tipova korisnika. No, jezgru i najveću populaciju još uvijek čine slijepe i slabovidne osobe. Kategoriju slabovidnih osoba čine mahom osobe starije životne dobi. Općenito, korisnici Hrvatske knjižnice za slijepe najvećim su dijelom srednje i treće životne dobi, dok paralelno s tim broj novoučlanjenih učenika s teškoćama u čitanju rapidno raste. Registriranih korisnika knjižničnih usluga i pretplatnika na časopise koje Knjižnica proizvodi ima oko 3000. Aktivne korisnike treba sagledati kroz posudbu kako bi se dobilo realno stanje. U 2016. godini, 1221 član posuđivao je naslove iz ovog fonda, dok je novoučlanjenih korisnika knjižničnih usluga bilo 166. Kroz razne programe, radionice i promidžbu nastoji se doći do onih kojima je usluga potrebna te se zadnjih nekoliko godina intenzivirala suradnja s udrugama slijepih, narodnim knjižnicama i školama na području Hrvatske.

Među korisnicima je najpopularnija usluga slanja knjiga poštom. Uslugu preuzimanja zvučnih knjiga putem internetske stranice Knjižnice, koja je pokrenuta 2015. godine, koristi 30\% članova, a učenici s teškoćama u čitanju i disleksijom odmah se upućuju na nju zbog praktičnih razloga. Neki korisnici s područja Zagreba i Zagrebačke županije vole posuđivati direktnim dolaskom, dok za one u nezgodnim situacijama postoji organizirana dostava knjiga na kućnu adresu. ${ }^{13}$

Posudbi zvučnih knjiga na CD-ima u 2016. godini bilo je 32.694, dok je naslova zvučnih knjiga preuzetih prošle godine putem interneta bilo 9694 . U usporedbi s navedenim brojkama, obrtaj knjiga na brajici je u prošloj godini bio malen i iznosi tek 688 posudbi. Ostatak fonda posuđivao se u zanemarivim brojkama, odnosno 44 . Na temelju ovih podataka može se zaključiti da korisnik Hrvatske knjižnice za slijepe u prosjeku pročita 35,3 knjige godišnje, što je vrlo dobar obrtaj relativno malenog fonda. ${ }^{14}$

Struktura članstva također diktira produkciju u formalnom i sadržajnom smislu. Određuje medij koji dominira i naslove koji se proizvode. Plan produkcije koji se donosi krajem godine,

\footnotetext{
${ }^{13}$ Za kulturno-obrazovne potrebe korisnika, Hrvatska knjižnica za slijepe organizira i brojna kolažna događanja i književne susrete, predavanja, poetska popodneva, male koncerte. Za članove koji ne mogu prisustvovati, snimke događanja šalju se kao prilozi zvučnom časopisu Znanost i umjetnost. Riječ je o jednom od 6 zvučnih časopisa koje Hrvatska knjižnica za slijepe proizvodi. Mjesečnik koji redovito izlazi od 1979. godine popularan je među korisnicima. U trajanju do 6 sati, zastupljene su teme iz popularne znanosti, umjetnosti te kraće književne forme.

${ }^{14}$ Podaci o fondu: zvučne knjige (MP3, DAISY, AUDIO), 3309; knjige i note na brajici, 2179 (od toga oko 650 nota); playaway format zvučne knjige, 56; xml (tekstualni oblik), 200; muzički CD-i, 65. Prošle je godine Knjižnica proizvela do sada rekordan broj, odnosno 157 novih naslova zvučnih knjiga. Odnosno, 2032 sata i 58 minuta pročitanog teksta.
} 
sastavljen je od želja i prijedloga korisnika, preporuka suradnika i djelatnika, prati se izdavaštvo, top-liste narodnih knjižnica, lektirni naslovi, te se popunjavaju propusti u fondu. Naglasak u produkciji je na zvučnim knjiga jer ga diktira potražnja. Zvučne knjige u studijima snimaju glumci, radijski spikeri, profesori hrvatskog jezika. Mnogi korisnici preferiraju jedne spikere, dok su im glasovi drugih odbojni. U mnogim knjižnicama u svijetu članovi mogu odabrati knjigu i prema glasu kojeg vole slušati. Kao i u narodnim knjižnicama, najviše se traži zabavna literatura, kriminalistički, ljubavni i pseudo-povijesni romani. Svaki korisnik u svom profilu ima obilježene preferirane žanrove, što uvelike olakšava posudbu. Budući da produkcija željenih naslova često ne može zadovoljiti glad čitatelja, korisnici posežu za raznorodnom literaturom. Nije rijedak slučaj da netko tko je čitao samo Browna i Ludluma iz "nužde" preslušava Dostojevskog i Manna. I obrnuto. Najaktivniji članovi posuđuju i preko 10 naslova mjesečno. Mnogim korisnicima, zvučne knjige su omiljeni način provođenja slobodnog vremena. Za puno njih, one su jedini način provođenja vremena uopće. Tada se više radi o suživotu s knjigama. Zvučne knjige postaju podlogom svakodnevice ili pak pozadinom koja neprestano žvrgolji, čak i dok se spava.

\section{Zaključak}

Zbog proizvodnog procesa izgradnje vlastitog fonda, knjižnica namijenjena osobama kojima standardni tisak nije čitljiv na neki je način hibrid između produkcijske kuće i narodne knjižnice. Put kojeg knjiga na standardnom tisku prolazi kako bi dospjela u oblik dostupan osobama koje ne mogu čitati standardni tisak, dug je i skup. Posredstvom tehnologije, taj se put kroz godine ipak nešto skratio, ali na njemu još uvijek postoji gomila prepreka, prije svega pravnih i financijskih. Populacija slijepih i slabovidnih osoba, budući da im je kretanje zbog izvanjskih faktora donekle ograničeno, a pristup sadržajima na televizijskom programu sveden na zvuk, željna je književnosti, literarne zabave, znanja i informacija. Njena potreba za dostupnim naslovima daleko nadvisuje njihovu proizvodnju te će se u budućnosti, posebice provedbom Ugovora iz Marakeša, djelovati prije svega na pojednostavljenju proizvodnje, distribucije i razmjene alternativnih oblika nekog djela.

\section{Literatura i izvori:}

1. Centar za odgoj i obrazovanje "Vinko Bek". "Specifični programi rehabilitacije”. http://www.centarvinko-bek-zg.skole.hr/nastava/specificni-programi-rehabilitacije?ms_nav=aad (preuzeto 31. 8. 2017).

2. Daisy consortium. http://www.daisy.org/home (preuzeto 31. 8. 2017).

3. Frajtag, Sanja. „50 nam je godina već". HKD Novosti 68 (2016). http://www.hkdrustvo.hr/hkdnovosti/ broj/65 (preuzeto 31. 8. 2017).

4. Hrvatski sabor. "Zakon o autorskom pravu". Narodne novine 167 (2003). http://narodne-novine.nn.hr/ clanci/sluzbeni/2003_10_167_2399.html (preuzeto 31. 8. 2017).

5. Keninger, Karen. "Why Braille?". Rad predstavljen na Tailoring the Reading Experience to Meet Individual Needs, Libraries Serving Persons with Print Disabilities 2016 Satellite Conference, Louisville, Kentucky, SAD, 11-12. kolovoza, 2016. Libraries serving persons with print disabilities. "LPD Satellite Conference: Tailoring the Reading Experience to meet Individual Needs". IFLA. https:// www.ifla.org/node/10839 (preuzeto 31. 8. 2017).

6. Maumet, Luc. "Accessibility in reading systems: what about dyslexia?". EdrLAB. https://www.edrlab. org/2017/06/20/accessibility-in-reading-systems-what-about-dyslexia/ (preuzeto 31. 8. 2017).

7. Šupe, Tanja. "Smjernice za izradu taktilne slikovnice”. U Hrvatska mreža školskih knjižničara. http://www.knjiznicari.hr/UDK02/index.php/Smjernice_za_izradu_taktilne_slikovnice_-_ Tanja_\%C5\%A0upe) (preuzeto 31. 8. 2017). 
8. WIPO. "Limitations and Exceptions: Access to Books for the Visually Impaired". http://www.wipo.int/ pressroom/en/briefs/limitations.html (preuzeto 31. 8. 2017).

9. WIPO. "Marrakesh Treaty to Facilitate Access to Published Works for Persons Who Are Blind, Visually Impaired or Otherwise Print Disabled". http://www.wipo.int/treaties/en/ip/marrakesh/ (preuzeto 31. 8. 2017).

\section{Beyond the Standard Print}

\section{Abstract}

The purpose of this paper is to describe the path that a written word on a standard print undergoes to reach those to whom it is not readable. Media, processes and formats that help produce accessible titles will be mentioned together with obstacles that occur along the way. Changes in technology (from analog to digital era; from cassettes to CD's and download service) together with changing tendencies in the structure of users (from blind persons to persons with print disabilities in general, mostly pupils with dyslexia) are transforming production of library holdings. On the example of the Croatian Library for the Blind, typical features and services for persons with print disabilities will be shown. User profile specificities and readers' habits tell how the hunger for literature outgrows production and availability of accessible formats.

Keywords: persons with print disabilities, Braille, talking book, assistive technology, blind persons, Croatian Library for the Blind, accessible formats

Примљено: 1. септембра 2017. Исправке рукописа: 28. септембра 2017. Прихваћено за објављивање: 3. октобра 2017. 